\title{
New magnetostratigraphy for the Olduvai Subchron in the Koobi Fora Formation, northwest Kenya, with implications for early Homo
}

\author{
Christopher J. Lepre ${ }^{\mathrm{a}, \mathrm{b}, *}$, Dennis V. Kent ${ }^{\mathrm{b}, \mathrm{c}}$ \\ a Anthropology Department, William Paterson University, Wayne, NJ, 07470, USA \\ b Lamont-Doherty Earth Observatory, Palisades, NY 10964, USA \\ ' Earth and Planetary Sciences, Rutgers University, Piscataway, NJ 08854, USA
}

\section{A R T I C L E I N F O}

\section{Article history:}

Received 3 August 2009

Received in revised form 10 December 2009

Accepted 14 December 2009

Available online 21 January 2010

Editor: M.L. Delaney

\section{Keywords:}

Olduvai Subchron

Pliocene-Pleistocene boundary

Homo erectus

Africa

\begin{abstract}
A B S T R A C T
A problematic magnetostratigraphy for the Koobi Fora Formation has contributed to debates on the evolutionary implications for early hominin fossils. To address this, 50 independent samples distributed over a nearly 63-m-thick interval were collected from the lower-middle KBS Member type section in fossil collection Area 102, northeast Turkana Basin. Characteristic directions obtained by thermal demagnetization define a coherent magnetostratigraphy that is supported by alternating-field studies on 28 sister specimens and the prior tephrochronological framework. Two long polarity intervals were recognized, each 30-40 m in thickness, and interpreted as the upper part of the normal polarity Olduvai Subchron and the overlying reverse polarity Matuyama Chron. The end Olduvai consists of a normal-reverse-normal polarity sequence occurring over a thickness of at least $1 \mathrm{~m}$ but perhaps up to $5 \mathrm{~m}$, suggesting that this subchron has a short reverse interval in its uppermost part. Such a fine-scale structure also has been reported from several other sites, like the Pliocene-Pleistocene boundary and point stratotype section at Vrica, Italy, which serves as a basis for formally delimiting three temporally discrete polarity subintervals for the Olduvai Subchron. These paleomagnetic results that place the upper boundary of the Olduvai at $\sim 48 \mathrm{~m}$ above the base of the KBS Member, coupled with published radioisotopic dates, firmly secure the age of partial cranium KNM-ER 3733 in the interval 1.78-1.48 Ma, with an interpolated age of $\sim 1.7 \mathrm{Ma}$, giving this fossil the most unambiguous numerical-age constraints, as compared to the oldest Homo cranial remains from Europe and Asia. Nonetheless, assured placement of the top of the Olduvai Subchron in the KBS Member is not sufficient in the face of other uncertainties to influence conventional interpretations of the timing and direction for the global dispersal of early Homo erectus.
\end{abstract}

(c) 2009 Elsevier B.V. All rights reserved.

\section{Introduction}

The timing and paleogeography of dispersal patterns are intricate components to the comprehensive understanding of hominin evolution. Central to these issues are the fossil-bearing outcrops of the KBS Member, Koobi Fora Formation, within the northeast Turkana Basin of northwest Kenya (Fig. 1). This member is part of the Plio-Pleistocene Omo Group (Brown and Feibel, 1986, 1991) and an important source for some of the oldest remains of the genus Homo in the world (Leakey and Leakey, 1978; Feibel et al., 1989; Wood, 1991; Antón and Swisher, 2004). At the type section along the Koobi Fora Ridge, the KBS Member is approximately $136 \mathrm{~m}$ thick (Fig. 2). It is defined as the sediments lying between the base of the KBS Tuff and the base of the Okote Tuff, which is followed within a few meters by the Lower Koobi Fora Tuff and the Koobi Fora Tuff (Brown and Feibel, 1986, 1991).

\footnotetext{
* Corresponding author.

E-mail address: leprec@wpunj.edu (C.J. Lepre).
}

Single-crystal-sanidine $\mathrm{Ar}^{39} / \mathrm{Ar}^{40}$ dating indicates that the KBS Tuff has an eruptive age of $1.869 \pm 0.021 \mathrm{Ma}$, whereas the Lower Koobi Fora and Koobi Fora tuffs have indistinguishable mean eruptive ages of $1.476 \pm 0.013 \mathrm{Ma}$ and $1.485 \pm 0.014 \mathrm{Ma}$, respectively (McDougall and Brown, 2006). Although not directly dated, the Okote Tuff, which lies between the Morutot Tuff $(1.607 \pm 0.019 \mathrm{Ma})$ within the KBS Member and the Morte Tuff $(1.510 \pm 0.016 \mathrm{Ma})$ in the Okote Member, is suggested to have an interpolated age of $1.56 \pm 0.05 \mathrm{Ma}$ (McDougall and Brown, 2006). Thus, the KBS Member represents approximately $300 \mathrm{kyr}$ of deposition, from about 1.87 to $1.56 \mathrm{Ma}$, with an average sediment accumulation rate of nearly $45 \mathrm{~cm} / \mathrm{kyr}$.

Even though the Omo Group is well constrained through over 100 tephrostratigraphic correlations and about 30 numerical tie points, internal age control for the KBS Member is limited by a paucity of directly dateable stratigraphic marker horizons (Feibel, 1997). This lack of internal dates has contributed to debates on the age of hominin fossils (Brown et al., 2006), with implications for sympatric relationships between taxa (Gathogo and Brown, 2006), variability within the hypodigm of early Homo (Walker, 2002), and the evolutionary homeland and initial global dispersal for Homo erectus (Dennell and 






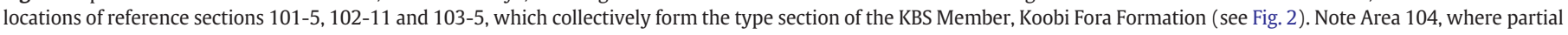
cranium KNM-ER 3733 (early African Homo erectus) was reported to have been collected.

Modified from Figs. 1 and 2 in Brown and Feibel (1986).

Roebroeks, 2005). Fundamental to these debates are the stratigraphic relationships between the local context of the fossils and the type section of the KBS Member at the Koobi Fora Ridge. A key to better correlations between the two is a detailed placement for the stratigraphic position of the top of the Olduvai Subchron within the Koobi Fora Formation. 


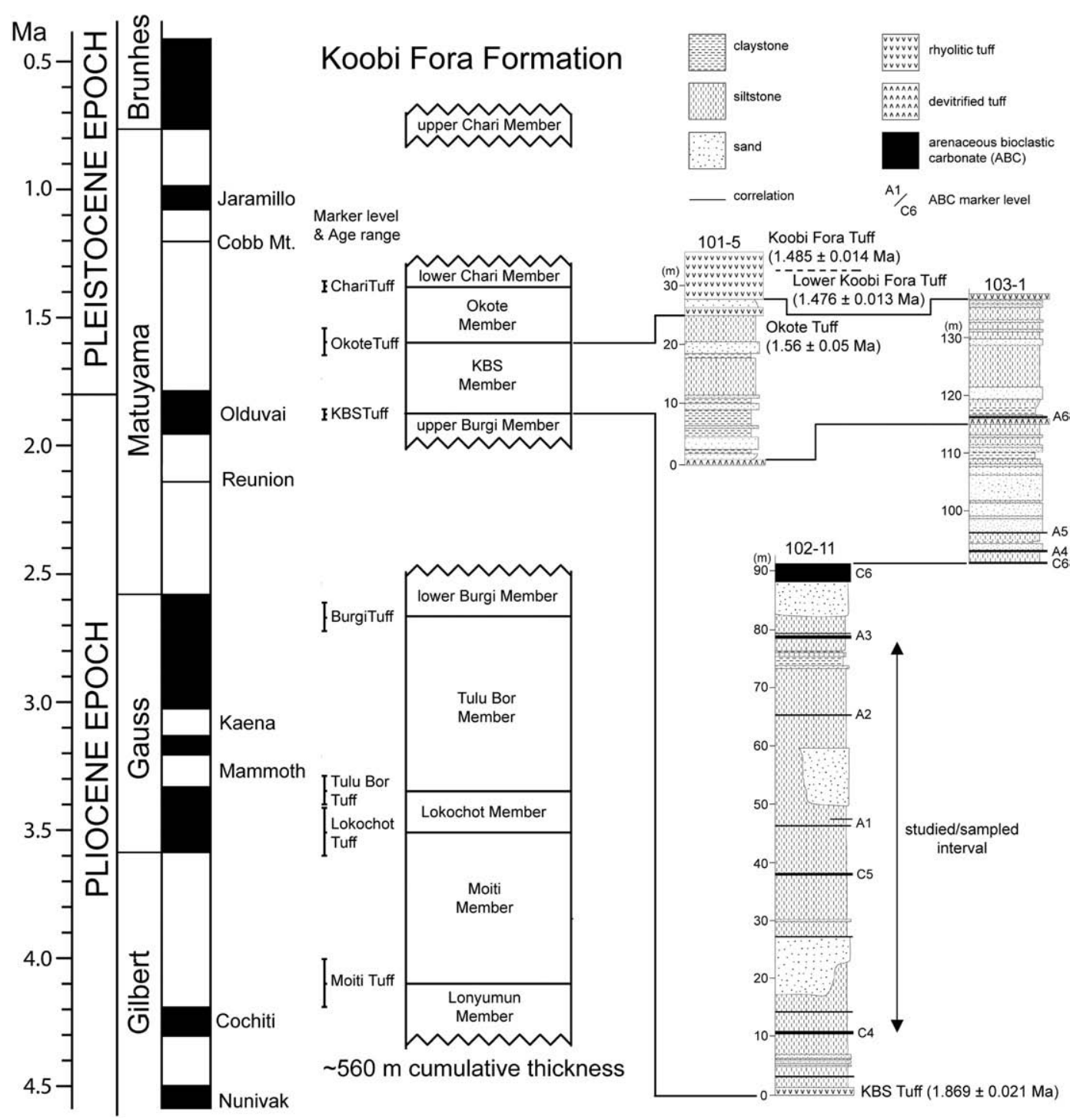







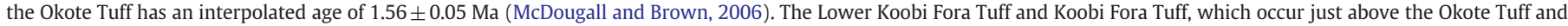

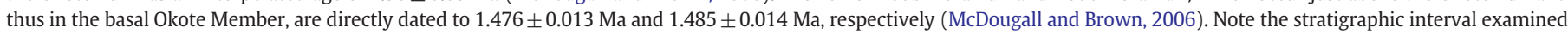
by this study, indicated by the double arrow alongside the lower part of section 102-11.

The Olduvai Subchron-named from its discovery locality at Olduvai Gorge, Tanzania, and one of the first magnetic polarity subchrons to be identified (Grommé and Hay, 1963; Cox et al., 1964)is a normal polarity interval within the reverse polarity Matuyama Chron (Fig. 2). According to astronomical timescale calibration, the Olduvai Subchron (Chron C2n according to the nomenclature of Cande and Kent (1992) extended from 1.945 to $1.778 \mathrm{Ma}$ and thus spans nearly $170 \mathrm{kyr}$ (Lourens et al., 2004). The Global Boundary Stratotype Section and Point (GSSP) for the base of the Pleistocene and the Plio-Pleistocene boundary is in the Vrica marine section in southern Italy and was placed close to the top of a normal polarity interval correlated to the Olduvai Subchron (Lourens et al., 2004). Astronomical calibrations for the climate-sensitive sapropels in the Vrica section indicate an age of $1.806 \mathrm{Ma}$ for the Pliocene-Pleistocene boundary (Lourens et al., 1996a,b, 2004). Considering that the KBS Member is constrained by radioisotopic dates at approximately 1.87 and 1.48 Ma (McDougall and Brown, 2006), it is of late Pliocene to early Pleistocene age. There is also little disagreement that the top of the Olduvai Subchron occurs somewhere within this interval of the Koobi Fora Formation (Hillhouse et al., 1986; Feibel et al., 1989; McDougall et al., 1992; Brown et al., 2006). However, its interpreted stratigraphic position within the KBS Member has varied in the paleomagnetic, lithostratigraphic, and tephrochronologic studies conducted over the last three decades.

Brock and Isaac (1974) developed an initial magnetostratigraphy for Plio-Pleistocene deposits of the northeast Turkana Basin, but this scheme was rife with problems, stemming from a miscorrelated lithostratigraphy and erroneous older dates for the KBS Tuff (cf., Cerling and Brown, 1982; McDougall, 1985; Brown and Feibel, 1986). To date, the only additional paleomagnetic results for the Koobi Fora Formation were provided by two closely related studies (Hillhouse et al., 1977, 1986). The latter of these (Hillhouse et al., 1986) used the same paleomagnetic data for the Koobi Fora Formation as the previous study (Hillhouse et al., 1977) for recognizing the top of the Olduvai Subchron, but had the advantage of more precise and accurate dates for the KBS Tuff (McDougall, 1985) in addition to a well-defined 
lithostratigraphic and tephrostratigraphic framework for the Koobi Fora Formation and Omo Group (Cerling and Brown, 1982; Brown and Feibel, 1986). Hillhouse et al. (1986) identified the position of the top of the Olduvai Subchron within the KBS Member but did not provide a detailed account of its vertical stratigraphic distance from the KBS Tuff or other marker levels (Fig. 3). Moreover, the approach used to determine characteristic remanent magnetizations only involved alternating-field demagnetization studies and subjecting most specimens to a single cleaning step of $10 \mathrm{mT}$ to $30 \mathrm{mT}$, depending on progressive demagnetization of pilot specimens. Hillhouse et al. $(1977,1986)$ recognized that this approach often yielded ambiguous polarity determinations from multiple levels of the KBS Member (Fig. 3), interpreted to be a consequence of variable remagnetization of the sediments, and admitted to the possibility of an overestimated thickness for the normal magnetozone (i.e., the Olduvai Subchron) within the KBS Member. Although not a focus of this study, it is worth noting that the recognition of the base of the Olduvai Subchron may also have been compromised by these variable remagnetizations, as Hillhouse et al. $(1977,1986)$ found normal polarities for $100-150 \mathrm{~m}$ beneath the KBS Tuff at the Koobi Fora Ridge in Area 102 (Fig. 3). The identification of this subchron's base in the Koobi Fora Formation has been also hampered by the presence of an unconformity (Feibel et al., 1989)-thought to represent about $500 \mathrm{kyr}$ of non-deposition from 2.5 to $2.0 \mathrm{Ma}$ (McDougall and Brown, 2008)-that divides the Burgi Member (2.68-1.87 Ma) in upper and lower parts (Fig. 2). Tuffs,

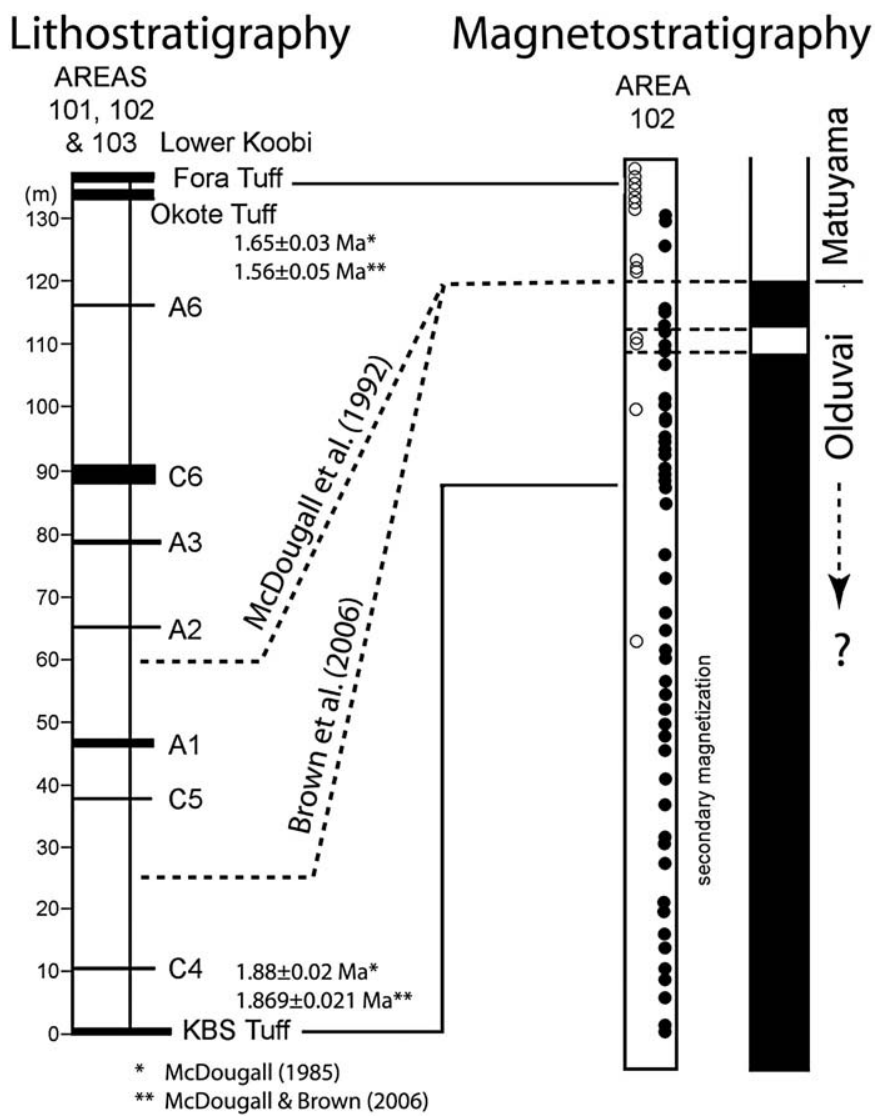

Fig. 3. Summary diagram of the problem. Lithostratigraphy and magnetostratigraphy after Brown and Feibel (1986) and Hillhouse et al. (1977, 1986), respectively. Stratigraphic placement of the top of the Olduvai Subchron at $\sim 60 \mathrm{~m}$ above the base of the KBS Tuff, as interpolated by McDougall et al. (1992). Placement of the top of the Olduvai at $25 \mathrm{~m}$ above the base of the KBS Tuff, between ABC marker levels C4 and C5, as interpolated by Brown et al. (2006). Note changes in the radioisotopic ages of tuffs reported by McDougall and Brown (2006) that correspond with the interpolation of Brown et al. (2006). which can be directly dated or correlated to a directly dated tuff, have not been located in the upper Burgi Member (Brown and Feibel, 1986; McDougall and Brown, 2008). At present, it is therefore not possible to adequately determine if the basal-most part of the Olduvai occurs above the unconformity or is truncated by it.

A subsequent study on the Koobi Fora Formation (McDougall et al., 1992) placed the stratigraphic position of the top of the Olduvai Subchron at $\sim 60 \mathrm{~m}$ above the base of the KBS Tuff within the KBS Member (Fig. 3). This interpretation (McDougall et al., 1992) was deduced from a small set of unpublished paleomagnetic data (Hillhouse, personal communication, 2009) in addition to synthesizing the results of Hillhouse et al. (1977) with tephrochronological data and lithostratigraphic evidence (McDougall, 1985; Brown and Feibel, 1986; Feibel et al., 1989). The datum of $60 \mathrm{~m}$ above the KBS Tuff was based on thickness measurements for the sedimentary succession Brown and Feibel (1986) designated as the lower-middle KBS Member type section, exposed in Area 102 along the Koobi Fora Ridge (Figs. 1 and 2).

Brown et al. (2006) have recently questioned the supposed location of the top of the Olduvai Subchron at $60 \mathrm{~m}$ above the KBS Tuff. Like McDougall et al. (1992), however, their evidence does not derive from newly published paleomagnetic data. Instead, it appears to be based on a linear-age interpolation for the $\sim 136 \mathrm{~m}$ of section from the KBS Tuff up to the Lower Koobi Fora Tuff, respectively redated to about 1.87 Ma and 1.48 Ma (McDougall and Brown, 2006) using updated monitor mineral ages (e.g., Spell and McDougall, 2003) (Fig. 2). The new age for the KBS Tuff of $1.87 \mathrm{Ma}$ reported by McDougall and Brown (2006) is not significantly different from the prior one of $\sim 1.88 \mathrm{Ma}$ (McDougall, 1985) but the $1.48 \mathrm{Ma}$ age of the Lower Koobi Fora Tuff is now approximately 170 kyr younger than a previously interpreted age of about 1.65 Ma (McDougall, 1985). According to the linear-age model of Brown et al. (2006), the interpolated stratigraphic position of strata with an age of $1.78 \mathrm{Ma}-$ corresponding to the astronomical age of the top of the Olduvai Subchron-would be only $\sim 25 \mathrm{~m}$ above the KBS Tuff. This is in fact where Brown et al. (2006, their Fig. 8) infer that the top of the Olduvai Subchron should occur (i.e., between marker horizons C4 and C5; Fig. 3 this study). Although not explicitly stated, it can be surmised that these authors (Brown et al., 2006) reached a similar conclusion as Hillhouse et al. (1977, 1986): secondary overprinting caused an overestimation for the true thickness of the normal polarity interval (i.e., the Olduvai Subchron) within the KBS Member.

As briefly discussed in Brown et al. (2006), a lowering of the top of the Olduvai Subchron to this new stratigraphic level implies that the ages of some Homo fossils in the KBS Member would get younger by at least $100 \mathrm{kyr}$. In particular, this would decrease the age of hominin fossil KNM-ER 3733. This fossil was collected from KBS Member deposits cropping out along the Koobi Fora Ridge in Area 104 (e.g., Fig. 1) and had an interpolated age of $1.78 \mathrm{Ma}$ (Feibel et al., 1989). Of all the near-complete cranial examples of early African $H$. erectus, KNM-ER 3733 is the geologically oldest (Wood, 1991). And its present age is more or less contemporaneous with the earliest Homo fossils from Asia and Eastern Europe (Antón and Swisher, 2004). Therefore, the age of KNM-ER 3733 is crucial to debates on the idea that $H$. erectus may have initially evolved in Eurasia and migrated into Africa (Dennell and Roebroeks, 2005; Ciochon, 2009).

To help clarify the stratigraphic context of the hominin fossil and the geochronology of the KBS Member type section, new field stratigraphic study and laboratory-based paleomagnetic analyses of the KBS Member deposits were conducted. Field research focused on the type section of the lower-middle KBS Member in Area 102, Koobi Fora Ridge, as defined by Brown and Feibel (1986) (Figs. 1 and 2). Firstly presented below is a description of the lower-middle KBS Member type section, the employed sampling strategies, and the analytical methods used to collect paleomagnetic data. Secondly, results and interpretations of the laboratory analyses are discussed. 
Thirdly, the data is used to interpret the structure and observed stratigraphic position of the top of the Olduvai Subchron within the Koobi Fora Formation. Lastly, previously reported geochronological schemes and fossil hominin dates are evaluated.

\section{Materials and methods}

As defined by Brown and Feibel (1986), the type section of the KBS Member crops out at the Koobi Fora Ridge, within fossil collection Area 101, Area 102, and Area 103 (Fig. 1). These areas are presently situated at approximately $3^{\circ} 50^{\prime} \mathrm{N}$ and $36^{\circ} 15^{\prime}$ E. Exposures of the KBS Member sediments occur along a series of badland-like outcrops, denuded by ephemeral streams that drain into the northeast shore of modern Lake Turkana. Tectonic activity (post-Koobi Fora Formation) has arranged the sedimentary outcrops into an en-echelon set of piggybacked fault blocks. Individual blocks dip down toward the S/SW up to $\sim 10^{\circ}$, with the uplifted part of the outcrops facing toward the N/NE.

KBS Member sedimentary strata of the Koobi Fora Ridge comprise loosely to semi-consolidated quartzo-feldspathic sand, sandy silt- stone, silty claystone, in addition to marker beds of arenaceous bioclastic carbonate $(\mathrm{ABC})$ dominated by bivalves, gastropods, and stromatolites. Prior studies have recognized that these KBS Member deposits were accumulated at a lake margin with alluvial, nearshore, and offshore depositional environments (Feibel et al., 1991; Brown and Feibel, 1991). Because of good cementation, resistance to weathering, visual prominence and distinctive fossil biota, the $A B C$ beds commonly uphold the Area 102 outcrops and facilitate correlations between the dissected sections of the KBS Member. Brown and Feibel $(1986,1991)$ have worked out formal alphanumeric codes and a marker-level sequence for the mollusk-dominated (e.g., C4, C5, and C6) or stromatolite-dominated (e.g., A1, A2, A3, A4, A5, and A6) $A B C$ beds of the KBS Member (Fig. 2). These ABC marker levels have been widely mapped throughout the northeast Turkana Basin (in some cases over an area of $200 \mathrm{~km}^{2}$ ) and are the rudiments to the lithostratigraphic framework for this part of the Koobi Fora Formation (Brown and Feibel, 1986, 1991).

The KBS Member type section (Fig. 2) is a composite of correlated reference sections from Area 101 (section 101-5), Area 102
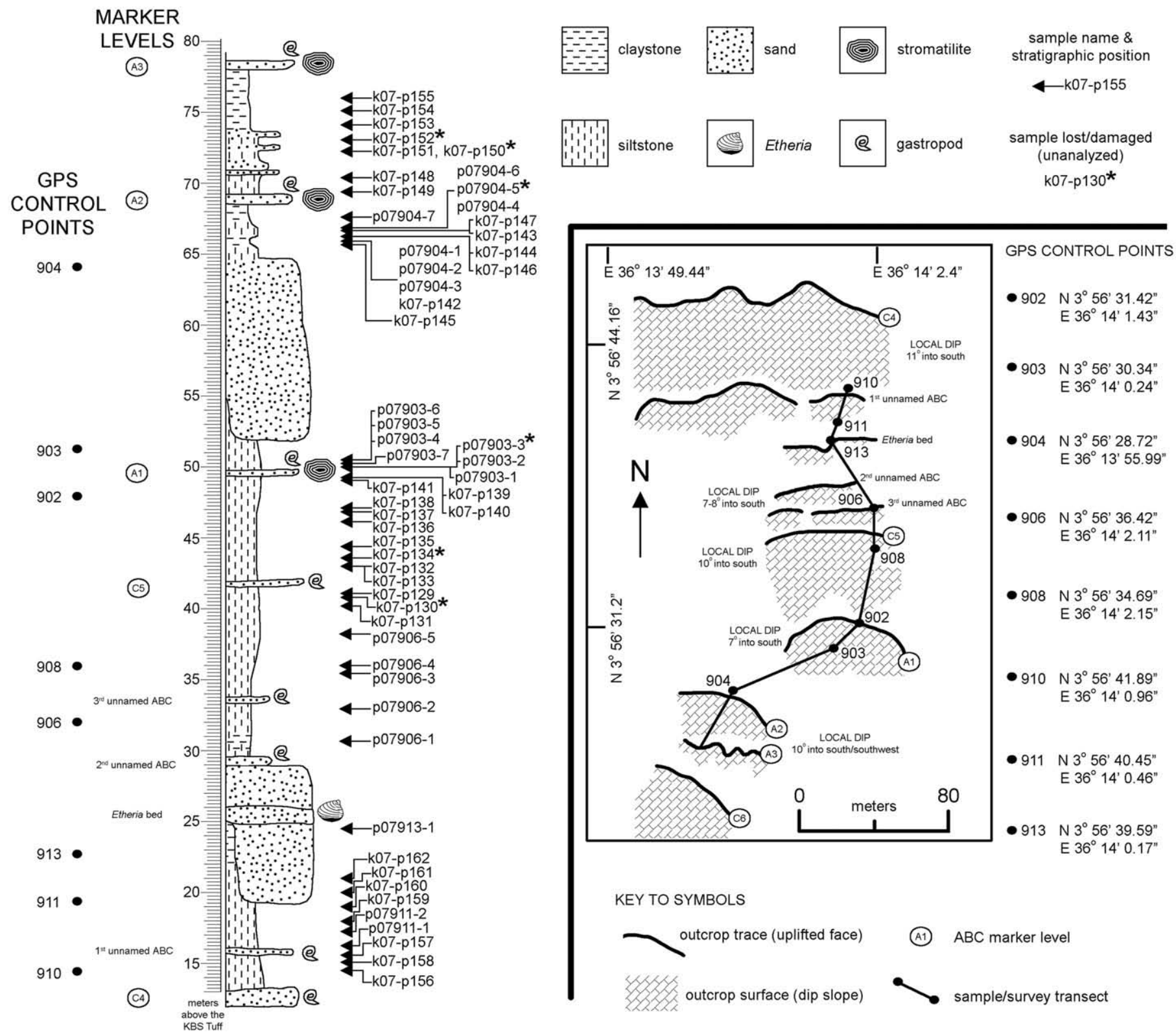

KEY TO SYMBOLS

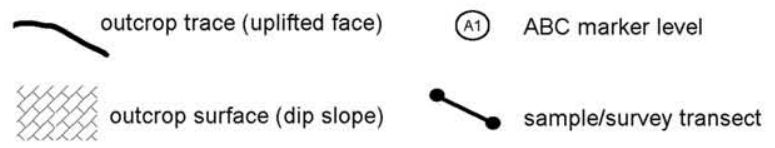

Fig. 4. Lithostratigraphy and modern geographic context of the studied interval of the lower-middle KBS Member, as exposed at the type section in Area 102. Section at left is keyed to the inset map through the marker levels and GPS control points. 
(section 102-11), and Area 103 (section 103-1) (Brown and Feibel, 1986). Of importance to this study is the lower-middle part of the KBS Member in Area 102, represented by reference section 102-11. This section is nearly 90 -m thick. It begins with the base of the KBS Tuff, which also defines the base of the KBS Member, and continues up to ABC marker level C6. The KBS Tuff and C6 bracket ABC marker levels C4, C5, A1, A2, and A3.

Sampling in Area 102 focused on the outcrops of the type occurrence of the lower-middle KBS Member that define section 102-11 of Brown and Feibel (1986). From this section (Fig. 4), oriented mudstone samples have been obtained from the stratigraphic interval formed by marker level C4 ( $\sim 13$ m above the KBS Tuff) up to marker level A3 ( 78 m above the KBS Tuff). Specifically, samples were collected from mudstones found within the four intervals defined by marker levels $\mathrm{C} 4$ and C5 ( 28.5 m thick; 18 independent samples), marker levels C5 and A1 ( $7.75 \mathrm{~m}$ thick; 10 independent samples), marker levels $\mathrm{A} 1$ and A2 ( $19.25 \mathrm{~m}$ thick; 20 independent samples), and marker levels A2 and A3 ( $10.5 \mathrm{~m}$; eight independent samples). Of the total interval, from C4 to A3, only two portions that consisted of coarse sand bodies, having thicknesses of 10-15 m, were not extensively sampled. One of the bodies occurs between marker levels C4 and C5, and the other between marker levels $\mathrm{A} 1$ and $\mathrm{A} 2$.

All samples collected from Area 102 derived from fresh surfaces exposed by digging into the outcrop for $50-100 \mathrm{~cm}$. Before sample
TD
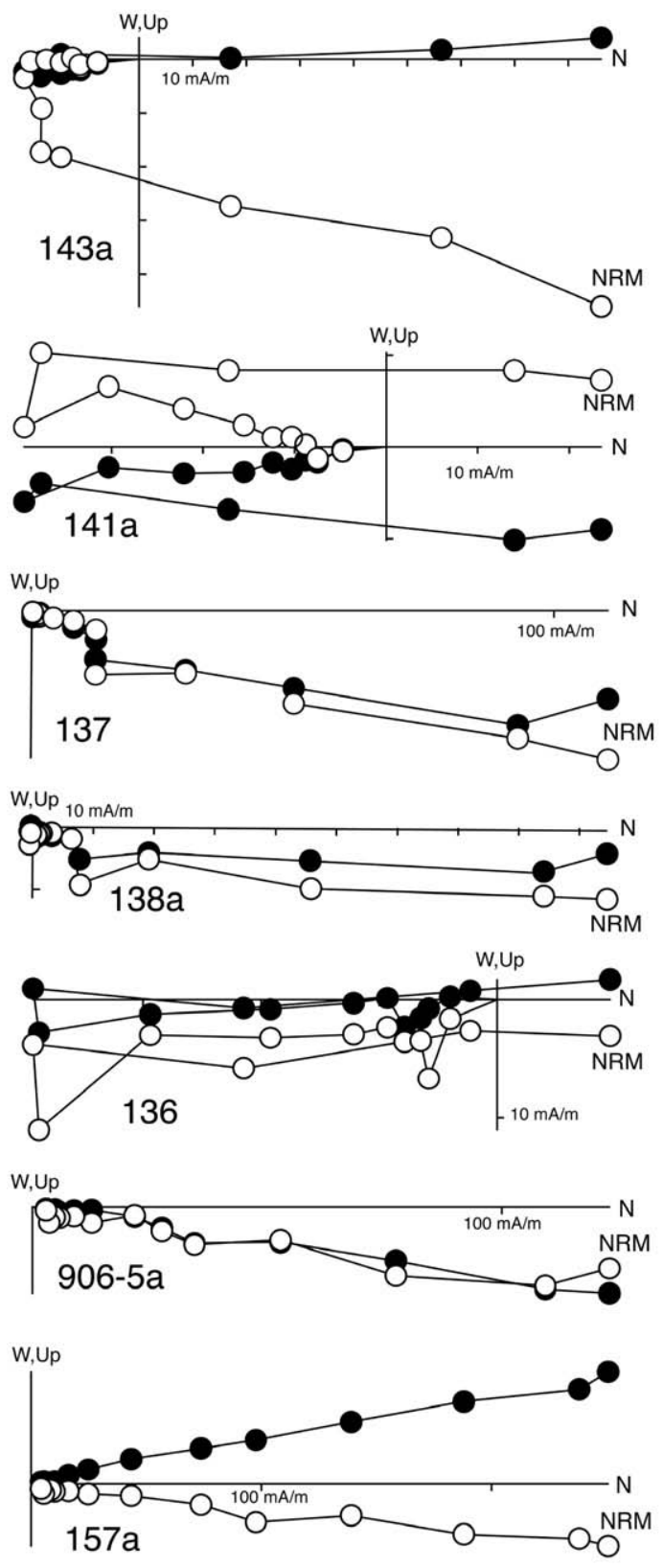

$\mathrm{AF}$

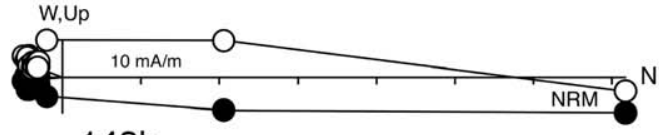

$143 b$
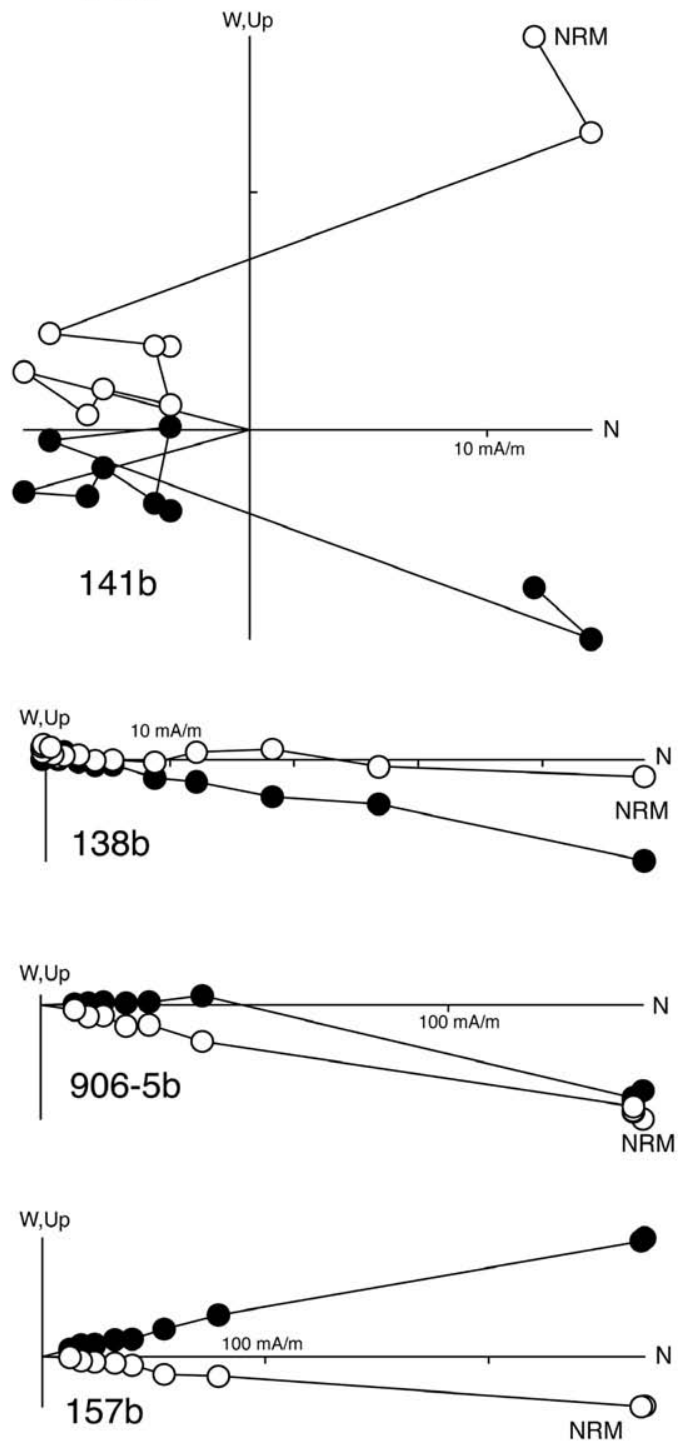

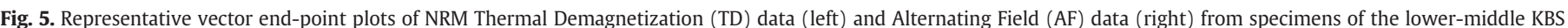



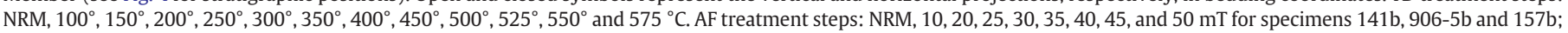
$\mathrm{NRM}$ and every $5 \mathrm{mT}$ to $75 \mathrm{mT}$ for specimens $138 \mathrm{~b}$ and $143 \mathrm{~b}$. 
Table 1

Paleomagnetic data for samples from the lower-middle KBS Member.

\begin{tabular}{|c|c|c|c|c|c|c|c|}
\hline $\begin{array}{l}\text { Level } \\
(\mathrm{m})\end{array}$ & Sample & Treat & $\begin{array}{l}\text { Dec. } \\
\left({ }^{\circ}\right)\end{array}$ & $\begin{array}{l}\text { Inc. } \\
\left({ }^{\circ}\right)\end{array}$ & $\begin{array}{l}\text { VGP lat. } \\
\left({ }^{\circ}\right)\end{array}$ & $n$ & $\begin{array}{l}\text { MAD } \\
\left({ }^{\circ}\right)\end{array}$ \\
\hline 76.10 & k07-p155 & TD & 139.0 & 28.7 & -45.1 & 5 & 11.8 \\
\hline 75.20 & k07-p154 & TD & 142.7 & 23.4 & -49.5 & 4 & 13.3 \\
\hline \multirow[t]{2}{*}{74.20} & k07-p153 & $\mathrm{AF}$ & 183.1 & -17.4 & & 7 & 3.7 \\
\hline & k07-p153 & TD & 14.3 & -10.1 & & 5 & 23.5 \\
\hline 72.30 & k07-p151 & TD & 176.2 & 2.9 & -83.4 & 5 & 8.4 \\
\hline \multirow[t]{2}{*}{70.40} & k07-p148 & TD & 177.9 & -2.1 & -86.4 & 5 & 3.6 \\
\hline & k07-p148 & $\mathrm{AF}$ & 181.7 & -2.2 & & 7 & 3.9 \\
\hline 69.40 & k07-p149 & TD & 181.0 & -5.4 & -88.4 & 5 & 3.0 \\
\hline \multirow[t]{2}{*}{67.60} & p07904-7 & TD & 181.8 & 8.1 & -81.7 & 5 & 4.4 \\
\hline & p07904-7 & $\mathrm{AF}$ & 179.2 & -10.7 & & 1 & $*$ \\
\hline \multirow[t]{2}{*}{66.90} & p07904-4 & TD & 167.0 & 17.9 & -71.5 & 4 & 11.7 \\
\hline & p07904-4 & $\mathrm{AF}$ & 183.8 & -4.5 & & 1 & * \\
\hline 66.90 & p07904-6 & TD & 177.5 & 2.4 & -84.2 & 5 & 5.6 \\
\hline 66.70 & k07-p147 & TD & 177.0 & -5.3 & -86.7 & 4 & 2.5 \\
\hline \multirow[t]{2}{*}{66.60} & k07-p143 & TD & 172.7 & 0.7 & -81.5 & 4 & 2.0 \\
\hline & k07-p143 & $\mathrm{AF}$ & 173.1 & -24.5 & & 7 & 9.4 \\
\hline 66.25 & k07-p144 & TD & 200.1 & -22.3 & -68.7 & 1 & $*$ \\
\hline 66.20 & k07-p146 & TD & 190.8 & -27.0 & -75.2 & 1 & * \\
\hline \multirow[t]{2}{*}{65.90} & p07904-3 & TD & 171.9 & 13.2 & -76.6 & 4 & 10.4 \\
\hline & p07904-3 & $\mathrm{AF}$ & 190.8 & -8.7 & & 1 & $*$ \\
\hline 65.90 & p07904-2 & TD & 181.1 & -5.0 & -88.1 & 4 & 6.7 \\
\hline 65.90 & p07904-1 & TD & 163.0 & 7.7 & -71.3 & 4 & 7.7 \\
\hline 65.90 & k07-p142 & TD & 179.8 & -8.7 & -89.6 & 1 & $*$ \\
\hline 65.70 & k07-p145 & TD & 200.6 & -31.5 & -66.0 & 1 & * \\
\hline 50.50 & p07903-5 & TD & 174.9 & -1.5 & -84.0 & 5 & 3.9 \\
\hline 50.50 & p07903-6 & TD & 177.2 & -3.9 & -86.5 & 5 & 3.7 \\
\hline 50.50 & p07903-4 & TD & 178.7 & -21.5 & -82.7 & 5 & 1.8 \\
\hline 50.25 & p07903-7 & TD & 178.0 & 1.3 & -84.9 & 5 & 1.9 \\
\hline 50.00 & p07903-2 & TD & 182.5 & -1.5 & -85.9 & 5 & 0.7 \\
\hline 50.00 & p07903-1 & TD & 177.1 & -6.1 & -87.0 & 5 & 1.5 \\
\hline \multirow[t]{2}{*}{49.35} & k07-p139 & TD & 169.6 & -2.8 & -79.3 & 5 & 2.4 \\
\hline & k07-p139 & $\mathrm{AF}$ & 176.2 & -11.1 & & 7 & 6.1 \\
\hline \multirow[t]{2}{*}{49.25} & k07-p140 & TD & 176.2 & -12.1 & -85.7 & 5 & 1.2 \\
\hline & k07-p140 & $\mathrm{AF}$ & 182.7 & -11.7 & & 7 & 5.1 \\
\hline \multirow[t]{2}{*}{49.10} & k07-p141 & TD & 173.4 & -10.4 & -83.3 & 5 & 3.5 \\
\hline & k07-p141 & $\mathrm{AF}$ & 164.6 & -13.9 & & 1 & $*$ \\
\hline 47.20 & k07-p138 & TD & 22.3 & 19.1 & 67.1 & 5 & 13.9 \\
\hline & k07-p138 & $\mathrm{AF}$ & 7.1 & 0.3 & & 7 & 6.3 \\
\hline 46.80 & k07-p137 & TD & 22.8 & 14.5 & 67.1 & 5 & 3.0 \\
\hline 46.20 & k07-p136 & TD & 177.3 & 8.8 & -81.2 & 5 & 5.4 \\
\hline 44.40 & k07-p135 & TD & 2.2 & -4.1 & 83.6 & 5 & 3.5 \\
\hline 43.10 & k07-p132 & $\mathrm{AF}$ & 342.9 & 3.2 & & 7 & 10.8 \\
\hline & k07-p132 & TD & 173.4 & -0.8 & & 5 & 15.9 \\
\hline 42.90 & k07-p133 & TD & 1.7 & 21.5 & 82.7 & 4 & 13.5 \\
\hline 41.10 & k07-p129 & TD & 358.6 & -17.5 & 77.0 & 5 & 1.4 \\
\hline & k07-p129 & $\mathrm{AF}$ & 348.4 & -12.0 & & 7 & 3.5 \\
\hline 40.20 & k07-p131 & TD & 358.3 & -10.1 & 80.8 & 5 & 2.5 \\
\hline & k07-p131 & $\mathrm{AF}$ & 4.8 & -7.7 & & 7 & 5.4 \\
\hline 38.30 & p07906-5 & TD & 7.1 & 9.5 & 82.9 & 5 & 4.5 \\
\hline & p07906-5 & $\mathrm{AF}$ & 358.2 & 11.4 & & 5 & 2.0 \\
\hline 36.25 & p07906-3 & TD & 359.6 & 10.6 & 88.6 & 6 & 1.6 \\
\hline & p07906-3 & $\mathrm{AF}$ & 355.7 & 9.6 & & 8 & 2.2 \\
\hline 35.25 & p07906-4 & TD & 352.2 & 6.4 & 82.2 & 5 & 3.6 \\
\hline & p07906-4 & $\mathrm{AF}$ & 349.0 & 0.6 & & 7 & 2.5 \\
\hline 32.75 & p07906-2 & TD & 350.1 & 7.5 & 80.1 & 5 & 1.7 \\
\hline 31.75 & p07906-1 & TD & 8.9 & 10.6 & 81.0 & 4 & 14.4 \\
\hline 24.50 & p07913-1 & TD & 356.7 & 14.9 & 85.1 & 5 & 7.1 \\
\hline 21.00 & k07-p162 & TD & 344.0 & 12.3 & 73.9 & 5 & 6.2 \\
\hline & k07-p162 & $\mathrm{AF}$ & 356.8 & 11.4 & & 7 & 3.0 \\
\hline 20.00 & k07-p161 & TD & 18.2 & 22.6 & 70.4 & 5 & 9.9 \\
\hline & k07-p161 & $\mathrm{AF}$ & 2.1 & 10.4 & & 8 & 1.9 \\
\hline 19.00 & k07-p160 & TD & 2.0 & 21.7 & 82.5 & 5 & 7.8 \\
\hline 18.00 & k07-p159 & TD & 355.9 & -2.6 & 83.3 & 4 & 9.4 \\
\hline & k07-p159 & $\mathrm{AF}$ & 359.5 & -0.9 & & 8 & 3.1 \\
\hline 17.25 & p07911-2 & TD & 6.6 & 5.7 & 83.3 & 5 & 3.3 \\
\hline & p07911-2 & $\mathrm{AF}$ & 355.9 & 3.8 & & 7 & 3.9 \\
\hline 16.25 & p07911-1 & TD & 359.1 & 6.7 & 88.9 & 5 & 2.2 \\
\hline & p07911-1 & $\mathrm{AF}$ & 356.0 & 5.4 & & 7 & 2.3 \\
\hline 15.60 & k07-p157 & TD & 347.4 & 7.1 & 77.4 & 5 & 1.9 \\
\hline & k07-p157 & $\mathrm{AF}$ & 347.2 & 6.5 & & 7 & 1.4 \\
\hline 15.10 & k07-p158 & TD & 359.3 & 6.5 & 89.0 & 5 & 2.2 \\
\hline 14.50 & k07-p156 & TD & 345.4 & 1.9 & 75.1 & 4 & 1.5 \\
\hline
\end{tabular}

$\mathrm{N}$

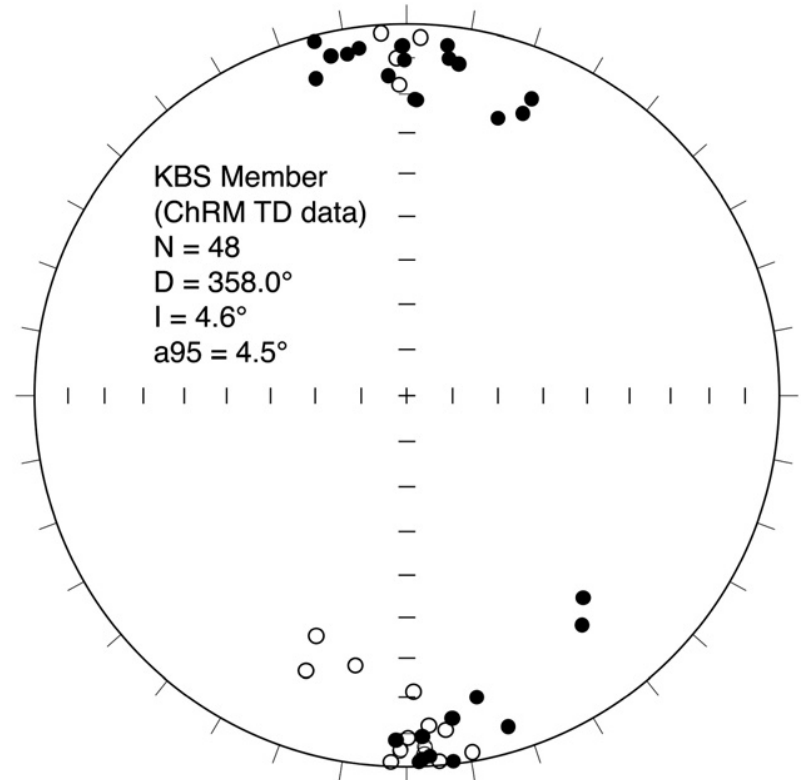

Fig. 6. Equal-area projection of the ChRM sample-mean directions of the lower-middle KBS Member. Open and closed symbols are projected onto the upper and the lower hemisphere, respectively, in bedding coordinates.

extraction occurred, in-situ azimuths and dips were determined using a standard orientation device (compass-inclinometer). These data were scribed onto a sample with a knife blade and an indelible pen. In the laboratory, samples were cut into standard cube-shape specimens ( $\sim 10 \mathrm{cc}$ ). In total, 56 independent samples were collected. Six of these were lost to damage that incurred during transport back to the United States or when sawed into specimens. Thus, laboratory studies involved specimens from 50 independent samples.

All magnetic remanence measurements were made with a $2 \mathrm{G} \mathrm{DC}$ SQUID rock magnetometer in the shielded room at the Paleomagnetics Laboratory of Lamont-Doherty Earth Observatory (Columbia University, U.S.A.). The natural remanent magnetization (NRM) of a specimen from all 50 samples was subjected to progressive Thermal Demagnetization (TD) in an initial step of $100{ }^{\circ} \mathrm{C}$, eight steps at $50^{\circ} \mathrm{C}\left(150-500{ }^{\circ} \mathrm{C}\right)$, and three steps at $25^{\circ} \mathrm{C}\left(525-575^{\circ} \mathrm{C}\right)$, for 12 steps in total. Twenty-four sister specimens of those used for TD studies were available for progressive Alternating Field (AF) demagnetization of NRM. AF pilot studies on five specimens were done in $5 \mathrm{mT}$ up to 75 or $80 \mathrm{mT}$; the remaining 19 specimens were adequately demagnetized using an initial step of $10 \mathrm{mT}$, a second step of $20 \mathrm{mT}$, and five or six steps at an increment of $5 \mathrm{mT}$ to 45 or 50 mT. Principal Component Analysis (PCA; Kirschvink, 1980) was used to fit least-square lines tied to the origin for the final demagnetization trajectories as revealed on orthogonal projection plots (Zijderveld, 1967). Magnetic susceptibility values were determined with a Bartington MS2B instrument for each specimen initially and after each TD heating step to monitor any magnetochemical alteration.

Notes to Table 1

Level $(\mathrm{m})$ is the stratigraphic height in meters from base of the KBS Tuff of the oriented sample. Treat is AF for Alternating Field and TD for Thermal Demagnetization technique used to isolate the characteristic magnetization direction (Dec, declination, and Inc inclination, in bedding coordinates), and corresponding VGP latitude, using Principal Component Analysis over $n$ steps giving MAD, maximum angular deviation, in degrees. Asterisk signifies samples where only last demagnetization step was used: $50 \mathrm{mT}$ for AF or $575^{\circ} \mathrm{C}$ for TD. Samples with MAD values larger than $15^{\circ}$ (in bold and italics) indicating low-quality data were not used for magnetostratigraphy interpretations. 


\section{Results of the magnetic measurements}

Sediments of the KBS Member are strongly magnetic with NRM intensities that ranged from about 1 to $600 \mathrm{~mA} / \mathrm{m}$. The main magnetic carrier is most probably magnetite, based on the fact that the NRM was typically reduced to a few percent by the terminal step of $575{ }^{\circ} \mathrm{C}$, which is close to the Curie point of magnetite, or by AF treatments of only $\sim 50 \mathrm{mT}$. This interpretation is consistent with previous studies for the Area 102 sediments (Hillhouse et al., 1977, 1986). However, while magnetite is the likely primary carrier for the characteristic remanence, previous research has demonstrated that many intervals of the Koobi Fora Formation preserve hematite, or another high-coercivity magnetic mineral, and oxidation-induced chemical remanent magnetization may contribute to the NRM (Hillhouse et al., 1986).

TD experiments adequately resolved characteristic directions in most every specimen analyzed. A linear demagnetization trend toward the origin is typically observed from $300{ }^{\circ} \mathrm{C}$ to the maximum TD step of $575^{\circ} \mathrm{C}$; this high-temperature component is regarded as the Characteristic Remanent Magnetization (ChRM). The ChRM component has a shallow northerly direction in samples from the lower part of the KBS Member (e.g., samples 157a, 906-5a, 137 and 138a in Fig. 5) and a shallow southerly direction, after the removal of an obvious overprint by $200-300{ }^{\circ} \mathrm{C}$, in samples from the upper part of the member (e.g., samples 141a and 143a in Fig. 5). Maximum angular deviation (MAD) values from principal component analyses on the high-temperature components are almost uniformly low with only two samples rejected for having MAD values greater than $15^{\circ}$. AF demagnetization data were generally consistent with the ChRM directions isolated with TD demagnetization, although the AF data tended to be noisier especially for reverse polarity samples (e.g., specimen 141a for TD versus companion specimen 141b for AF in Fig. 5). We relied on the TD data for magnetostratigraphic interpretations (Table 1).

An equal-area projection of mean ChRM directions of the 48 accepted samples based on TD data (Fig. 6) clearly demonstrates the paleomagnetic directions separate into northerly and southerly groups that pass a reversal test (antipodal within $7.7^{\circ}$; Category B according to classification scheme of McFadden and McElhinny, 1990). After inverting the southerly (reverse) directions to common northerly (normal) polarity and correcting for $10^{\circ}$ southerly bedding tilt, the overall mean direction is $D=358.0^{\circ} I=4.6^{\circ}$ alpha95 $=4.5^{\circ}$, which is slightly shallower but nonetheless not significantly different than the expected geocentric axial dipole field for the locality $\left(D=0^{\circ} I=8^{\circ}\right)$.

\section{Magnetostratigraphic interpretations}

Virtual geomagnetic pole (VGP) latitudes calculated for sample ChRM directions plotted versus stratigraphic thickness delineate two comparatively long polarity intervals in the examined part of the KBS Member (Fig. 7). A first interval-consisting mainly of normal polarity (positive) VGP latitudes-begins just above marker unit C4 ( 13 m above the KBS Tuff) and ends at about $49 \mathrm{~m}$ above the KBS Tuff, which is also of normal polarity (Hillhouse et al., 1977, 1986). However, it is punctuated by a thin interval of reverse polarity defined by one sample at $46 \mathrm{~m}$ with excellent demagnetization behavior plus a present-day field overprint that precludes misorientation (sample 136 in Fig. 5). We refer to this lower normal polarity interval as magnetozone KBS1n and its constituent polarity subzones from base upward as KBS1n.1n, KBS1n.1r, and KBS1n.2n. The second intervalcomprising reverse polarity (negative) VGP latitudes-begins between marker levels $\mathrm{C} 5$ and $\mathrm{A} 1$ at about $49 \mathrm{~m}$ above the KBS Tuff and continues to just below stratigraphic marker unit A3 ( $\sim 78 \mathrm{~m}$ above the KBS Tuff), the upper limit of the sampled section; we refer to this magnetozone as KBS1r.
High precision radioisotopic dates (McDougall and Brown, 2006) that bracket the KBS Member between 1.869 and $1.476 \mathrm{Ma}$ allow an unambiguous correlation of the magnetostratigraphy to the Geomagnetic Polarity Time Scale (GPTS, e.g., Berggren et al., 1995; Cande and Kent, 1995; Lourens et al., 2004). In particular, magnetozone KBS1 $\mathrm{n}$ that is minimally $37 \mathrm{~m}$ thick can be correlated to the later part of the Olduvai Subchron (Subchron C2n) and magnetozone KBS1r that is minimally $30 \mathrm{~m}$ thick to a succeeding portion of the Matuyama Chron (C1r.2r) (Fig. 7). Sample magnetizations at around $66 \mathrm{~m}$ tended to be poorly resolved (i.e., samples 142, 144, 145 and 146 just above a sampling gap across a thick sandstone; Table 1). Of greater potential significance, however, is the normal-reverse-normal character of the upper part of magnetozone KBS1n. This may correspond to a parallel character sometimes seen in the transition from the Olduvai to Matuyama, for example, in one of the earliest magnetostratigraphic studies of deep-sea sediment cores (Ninkovich et al., 1966) but most notably in the Pliocene-Pleistocene boundary and point stratotype section from Vrica, Italy. Paleomagnetic studies at Vrica (Tauxe et al., 1983; Zijderveld et al., 1991) defined the top of the Olduvai Subchron as consisting of a normal-reverse-normal polarity succession. Sapropel correlations of the more recent study (Zijderveld et al., 1991) were used (Lourens et al., 2004) to make astronomical calibrations for the sapropel sequence and develop a detailed chronology that we use as a basis for correlating the Koobi Fora magnetostratigraphy.

New KBS Member paleomagnetic results reported here indicate that the transition of the Olduvai Subchron (C2n) to the Matuyama Chron (C1r.2r) is characterized by a N-R-N succession of polarities (Fig. 8). Placing boundaries of the polarity changes at midpoints between the stratigraphic positions of sampling levels, this polarity succession (KBS1n.1r and KBS1n.2n) spans about $3 \mathrm{~m}$ of section, from about 45 to $48 \mathrm{~m}$ above the KBS Tuff, but given the sampling distribution is constrained to be between $\sim 1 \mathrm{~m}$ and $\sim 5 \mathrm{~m}$ thick. According to the astronomical calibration of the Vrica magnetostratigraphy (Lourens et al., 2004), this polarity sequence should span about $52 \mathrm{kyr}(1.830$ to $1.778 \mathrm{Ma})$. Such a timing would imply a nominal sediment accumulation rate of $\sim 6 \mathrm{~cm} / \mathrm{kyr}$ (range between 2 and $10 \mathrm{~cm} / \mathrm{kyr}$ ) across this interval of the KBS Member. This rate may be more representative of the mudstone facies, whereas the presence of thick sand bodies elsewhere in the section may contribute to the higher overall mean sediment accumulation rate of $\sim 45 \mathrm{~cm} / \mathrm{kyr}$ estimated for the entire KBS Member.

To summarize, the top of magnetozone KBS1n, which occurs between $\mathrm{ABC}$ marker levels $\mathrm{C} 5$ and $\mathrm{A} 1$ at $\sim 48 \mathrm{~m}$ above the base of the KBS Tuff, can be correlated to the top of the Olduvai Subchron (Chron C2n; Figs. 7 and 8). This global magnetic polarity boundary has an astronomical age of $1.778 \pm 0.003 \mathrm{Ma}$ (Horng et al., 2002; Lourens et al., 2004). An interval of alternating polarity characterizes the transition from the normal Olduvai Subchron to the reverse Matuyama Chron and spans from about 45 to $48 \mathrm{~m}$ above the KBS Tuff. Such a fine-scale structure for the top of the Olduvai Subchron has been observed in some previous work-for example: North Pacific deep-sea sediment core V20-109 (Ninkovich et al., 1966), North Atlantic sediment core from Deep Sea Drilling Project Site 609B (Clement and Kent, 1987), and Chinese loess deposits (Heller et al., 1991) - most notably in the Pliocene-Pleistocene stratotype section at Vrica, Italy (Tauxe et al., 1983; Zijderveld et al., 1991), lending independent support for the magnetostratigraphic correlation. On the strength of these multiple records and according to criteria for distinguishing polarity intervals from polarity excursions (Krijgsman and Kent, 2004), the Olduvai Subchron might be formally subdivided into three polarity intervals. In ascending numeric designation from younger to older (as is the custom with the GPTS) these would be $\mathrm{C} 2 \mathrm{n} .1 \mathrm{n}, \mathrm{C} 2 \mathrm{n} .1 \mathrm{r}$ and $\mathrm{C} 2 \mathrm{n} .2 \mathrm{n}$, with estimated ages based on astronomical calibration of the sapropel sequence at Vrica (option II of Zijderveld et al., 1991; Lourens et al., 1996a, 2004) (Table 2). 
One implication of this fine-scale correlation is that the section across the upper Olduvai transition should be quite complete in these continental deposits of Koobi Fora, allowing for future detailed studies of the collapse, rise and overall behavior of the geomagnetic field during multiple reversals in rapid succession. It also suggests that the KBS Member is a high-resolution record and probably preserves information for events occurring on the order of $10^{4}$ years. This lends support to the previous interpretation (Lepre et al., 2007) that Milankovitch-climate forcing may have played a role in the deposition of the lake-margin facies sequences from which the upper Olduvai transition has now been recognized. Finally, given that Chron $\mathrm{C} 2 \mathrm{n} .1 \mathrm{r}$ constrains the Pliocene-Pleistocene boundary, which is defined as at the top of sapropel 'e' in the Vrica section (1.806 Ma; Lourens et al., 2004), the similar polarity interval identified at Koobi Fora allows for the detailed recognition of this datum. Future research concerning the Pliocene-Pleistocene boundary, which occurs at around the 46-m level (Fig. 8), may therefore consider the KBS Member as a rare terrestrial analogue that is well defined through depositional facies, radioisotopic dates, and paleomagnetic stratigraphy.

\section{Age of KNM-ER 3733 and other earliest $H$. erectus fossils}

Featured prominently in scenarios of early Homo evolution and the initial dispersal of hominins from Africa is the partial skull KNM-ER 3733 from the KBS Member of the Koobi Fora Formation. This specimen was found at a stratigraphic level some $6 \mathrm{~m}$ above a correlate of the A2 marker unit in fossil collection Area 104 and ascribed an interpolated age of about $1.78 \mathrm{Ma}$ (Feibel et al., 1989). KNM-ER 3733 is typically described as the geologically oldest of the most intact cranial specimens of early African H. erectus (Wood, 1991; Antón and Swisher, 2004). Also documented from the Koobi Fora Formation are a series of Burgi Member fossils from below the KBS Tuff that are suspected to be within a lower portion of the normal polarity Olduvai Subchron (Feibel et al., 1989). These highly fragmentary cranial remains (i.e., KNM-ER 2598 and KNM-ER 3732) and few postcranial fossils of "large-bodied hominins" (i.e., KNM-ER 3228 and KNM-ER 1481) are considered to potentially be the oldest evidence for the first global appearance of this taxon (Wood, 1991; Antón and Swisher, 2004). Older age limits for these presumed examples of early African $H$. erectus of pre-KBS-Tuff age are poorly defined, as this part of the Burgi Member lacks directly dated tuffs and includes an unconformity that is not well constrained in time (Fig. 2). However, although published paleomagnetic data for this part of the Burgi Member (Fig. 3 this study; Hillhouse et al., 1977, 1986) have an uncertain stratigraphic relationship to the unconformity and may be affected by variable remagnetizations, the normal magnetizations that extend below the KBS Tuff may in fact record the Olduvai Subchron. If confirmed, this would imply that the oldest fragmentary remains of early African $H$. erectus may extend back to not more than $1.945 \mathrm{Ma}$, the estimated astronomical age for the onset of the Olduvai Subchron.

The interpolated age of KNM-ER 3733 is provocatively close to the estimated ages for the oldest out-of-Africa hominin remains in the world. These include the $H$. erectus incisor tooth from Yuanmou Basin in China (Zhu et al., 2008), the H. erectus sensu lato cranial fossils from the site of Dmanisi, Georgia (Gabunia et al., 2000) and the H. erectus partial skull from the Perning locality on the island of Java, Indonesia (Swisher et al., 1994). Collectively, the data have conventionally been interpreted to suggest that $H$. erectus dispersed from Africa, over a period on the order of $10^{5}$ years, after initially evolving on this continent at $>1.87 \mathrm{Ma}$ (e.g. Antón and Swisher, 2004). An alternate but not widely accepted point of view, however, is that $H$. erectus initially evolved in Asia and dispersed into other parts of the Old World (Dennell and Roebroeks, 2005; Ciochon, 2009). Some arguments in support of this latter hypothesis (e.g., Dennell, 2007) have cited a younger estimated age for KNM-ER 3733 of $1.68-1.65 \mathrm{Ma}$ proposed by Brown et al. (2006) based on their interpolated repositioning of the top of the Olduvai Subchron in the Koobi Fora Formation (e.g., Fig. 3).

Results of the study presented here provide some clarity for these issues. First, prior hypotheses that place the top of the Olduvai Subchron at either $\sim 25 \mathrm{~m}$ (Brown et al., 2006) or $\sim 60 \mathrm{~m}$ (McDougall et al., 1992) above the KBS Tuff are incompatible with the new magnetostratigraphic data. These stratigraphic levels would ostensibly position the top of the Olduvai either within the upper part of the normal Olduvai Subchron or the overlying portion of the reverse Matuyama Chron, respectively (Fig. 7). With the new magnetostratigraphic data, an average sediment accumulation rate of $\sim 29 \mathrm{~cm} / \mathrm{kyr}$ can be estimated for the $\sim 88 \mathrm{~m}$ of middle-upper KBS Member bracketed by the top of the Olduvai Subchron $(1.778 \pm 0.003 \mathrm{Ma}$; Horng et al., 2002; Lourens et al., 2004) and the base of the Lower Koobi Fora Tuff $(1.476 \pm 0.013 \mathrm{Ma}$; McDougall and Brown, 2006). Using this rate, the A2 marker unit in Area 102, at $20 \mathrm{~m}$ above the Olduvai Subchron, has an estimated age of $1.71 \mathrm{Ma}$; the KNM-ER 3733 fossil, which Feibel et al. (1989) place at about $6 \mathrm{~m}$ above the correlate of the A2 marker unit, is just younger (Fig. 7). Given the various uncertainties, this interpolated age is not substantially different than the interpolation of 1.78 Ma determined by Feibel et al. (1989) for A2, especially considering that the highly erosive, channel-form sand bodies within the Area 102 section likely complicate the age estimates derived from linear interpolation. A more exact age for KNM-ER 3733 , however, will also require geochronological data to be obtained directly from the Area 104 outcrop from which the fossil was retrieved. As it stands, the age of KNM-ER 3733 may perhaps prove to be slightly younger ( $\leq 1.7 \mathrm{Ma}$ ) in light of the work by Feibel et al. (1989) that places the stratigraphic position of this fossil at about $6 \mathrm{~m}$ above the correlate of the A2 marker unit.

Regardless of what the most accurate date for KNM-ER 3733 turns out to be, it is difficult to compare the chronology of this fossil to the oldest out-of-Africa hominin remains because of the quality of age control (especially upper age control) on the European and Asian sites. This ultimately hinders detailed interpretations of the timing and paleogeography of early Homo dispersals. For example, of all the out-of-Africa Homo fossils of similar age to KNM-ER 3733, the cranial material from Perning would appear to be the best constrained at $1.81 \pm 0.04 \mathrm{Ma}$ to $>1.778 \mathrm{Ma}$. The lower age limit was based on ${ }^{40} \mathrm{Ar} /{ }^{39} \mathrm{Ar}$ dating of volcaniclastics in stratigraphic association with the sediment from which the $H$. erectus material was collected; the upper age limit derived from paleomagnetic results on six oriented samples that indicated claystones interbedded with the volcaniclastics preserve normal polarities interpreted as the Olduvai Subchron (Swisher et al., 1994). However, the

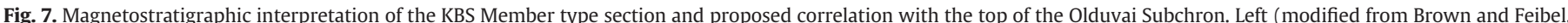

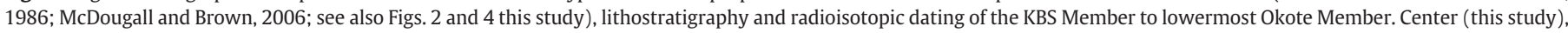

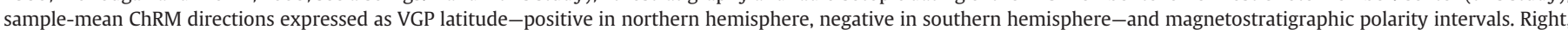

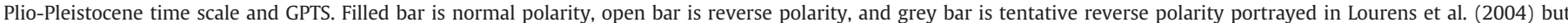

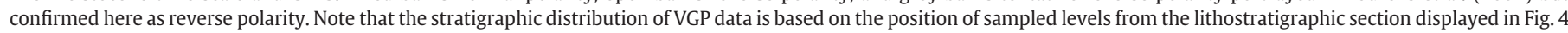

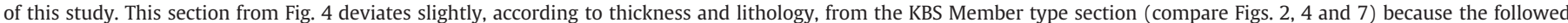

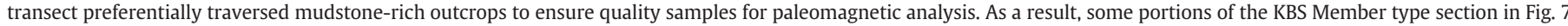

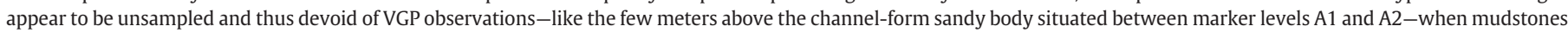
were in fact collected and analyzed for these locations (e.g., Fig. 4 and Table 1). 
polarity and subchron interpretations should be considered with caution because the associated primary data have not been published and therefore the quality of the results (which are reported to have a 'reversed hematite overprint') has yet to be independently evaluated. This in fact suggests that the upper age limit for Perning is not well defined.

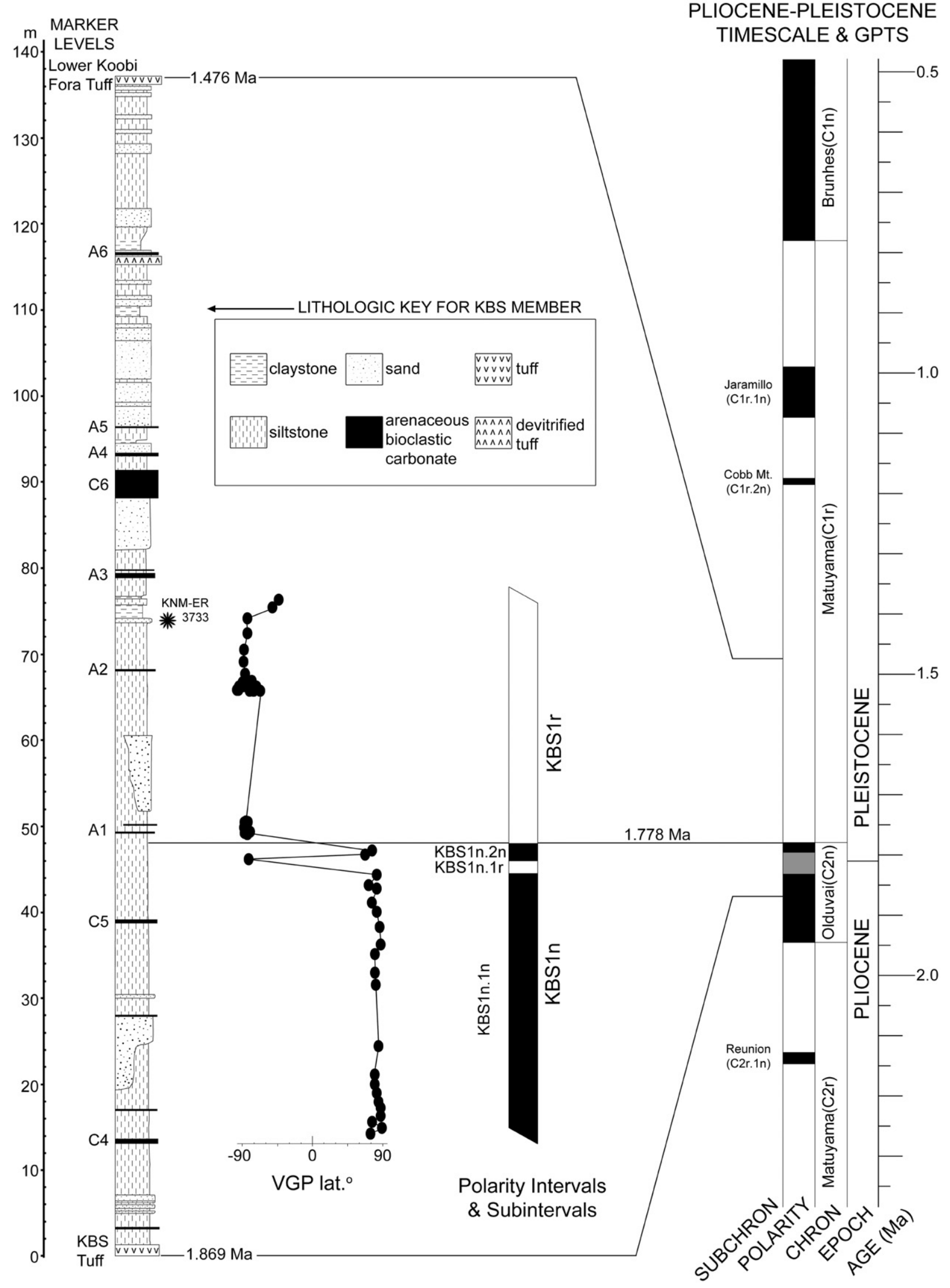




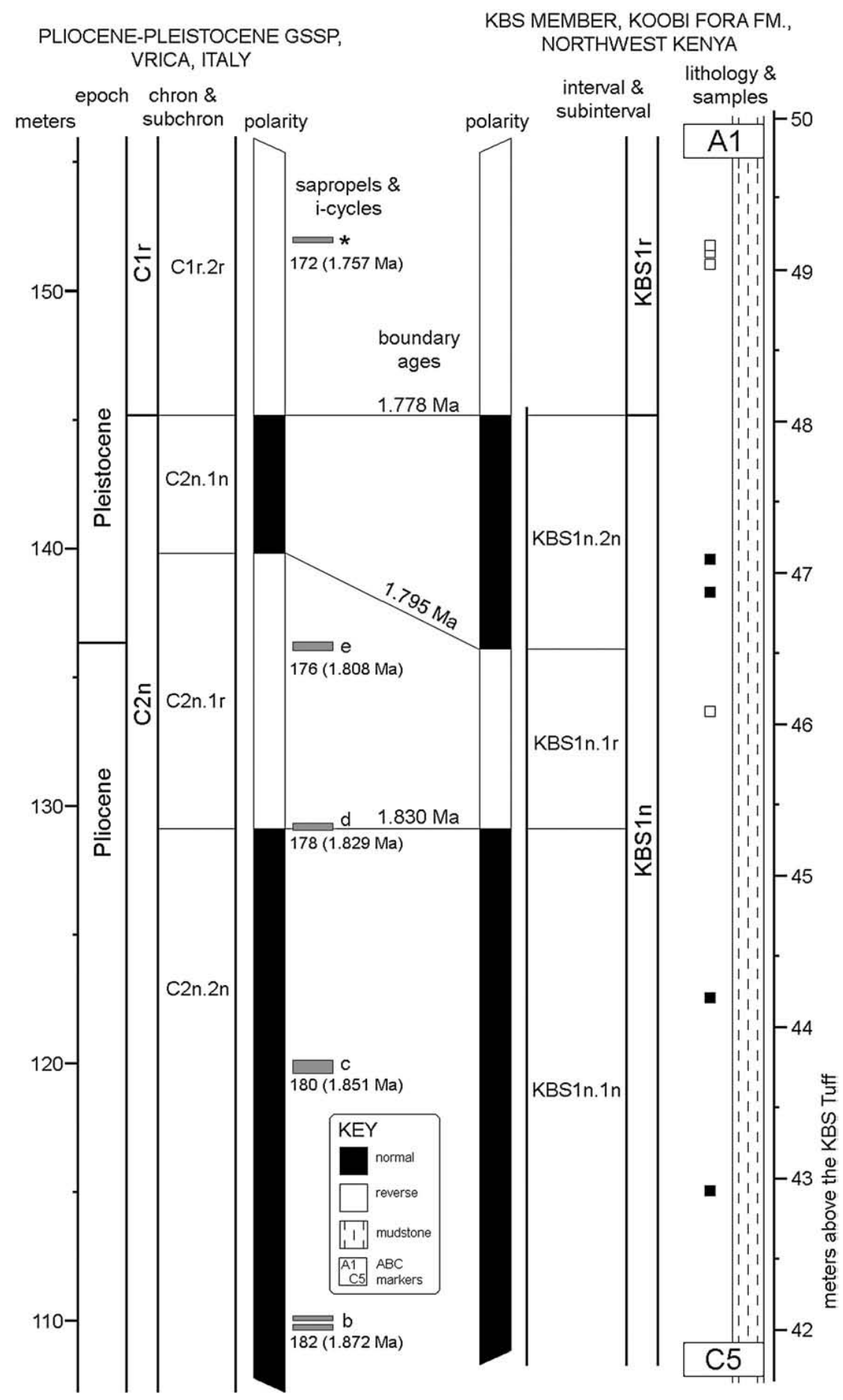

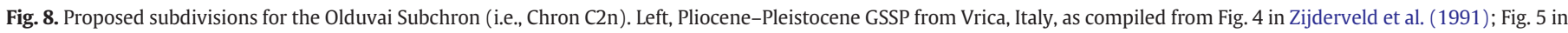

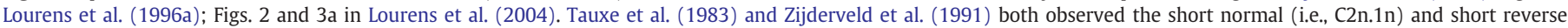

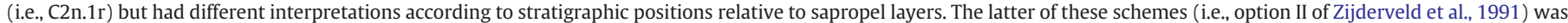

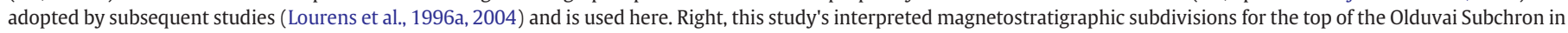

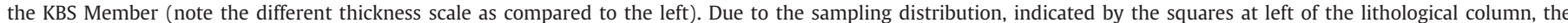

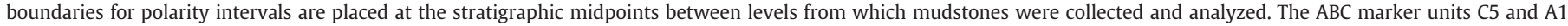


possibly caused by the types of Milankovitch-climate forcing recorded in the Vrica section (Lepre et al., 2007).

Homo cranial specimens from Dmanisi are thought to be within the reverse Matuyama Chron (C1r.2r), just above the top of the Olduvai. This interpretation is based on an $\mathrm{Ar}^{39} / \mathrm{Ar}^{40}$ plateau age of $1.85 \pm$ $0.01 \mathrm{Ma}$ for basaltic lavas (of normal polarity) that underlie the site and sediments of reverse polarity surrounding the fossils (Gabunia et al., 2000). There is no direct numerical date for upper age control but the presence of a typical late Pliocene to early Pleistocene mammalian assemblage, especially the rodents Mimomys ostramosensis and $M$. tornesis, suggested that the hominin fossils are not younger than $\sim 1.6 \mathrm{Ma}$ (Gabunia et al., 2000). However, with the unresolved state of the magneto-biochronology for Pliocene-Pleistocene Europe (see Gibert et al., 2007 and references within, for 
Table 2

Proposed subdivisions for the Olduvai Subchron (Chron $\mathrm{C} 2 \mathrm{n}$ ) following the conventional nomenclature for polarity chrons and subchrons (Cande and Kent, 1992). Ages derived from Lourens et al. (1996a, 2004).

\begin{tabular}{llll}
\hline Subchron & $\begin{array}{l}\text { Young } \\
(\mathrm{Ma})\end{array}$ & $\begin{array}{l}\text { Old } \\
(\mathrm{Ma})\end{array}$ & $\begin{array}{l}\text { Duration } \\
(\mathrm{Myr})\end{array}$ \\
\hline $\mathrm{C} 2 \mathrm{n} .1 \mathrm{n}$ & 1.778 & 1.795 & 0.017 \\
$\mathrm{C} 2 \mathrm{n} .1 \mathrm{r}$ & 1.795 & 1.830 & 0.035 \\
$\mathrm{C} 2 \mathrm{n} .2 \mathrm{n}$ & 1.830 & 1.945 & 0.115 \\
\hline
\end{tabular}

example), there is the possibility that the hominin fossils are more geologically recent than currently interpreted.

Inferred to be from a similar reverse magnetostratigraphic interval of the Matuyama Chron (C1r.2r) are paleontological localities within the Yuanmou Basin, China that preserve sparse dental evidence of $H$. erectus. The Yuanmou sequences lack radioisotopic age data; however, reverse polarities indicate that the section is within the Matuyama Chron, and what are identified as the Olduvai and Reunion subchrons provide lower age constraints but occur tens of meters below the fossil horizon in an adjacent correlative section (Zhu et al., 2008). The date of the tooth is extrapolated through sedimentation rates, as estimated from the thickness of strata allocated to the Olduvai Subchron and from the thickness of strata constrained by the top of the Olduvai and the top of the Reunion Subchron. The fossil horizon has an estimated date of around $1.7 \mathrm{Ma}$, with an upper age limit inferred to be $\sim 1.6 \mathrm{Ma}$, although there are no specific upper age constraints beyond Matuyama (Zhu et al., 2008).

Accordingly, we would suggest that in comparison to the Perning, Dmanisi and Yuanmou examples, KNM-ER 3733 has the least ambiguous younger and older numerical-age constraints due to the radioisotopic dates on the KBS $(\sim 1.87 \mathrm{Ma})$ and Lower Koobi Fora $(\sim 1.48 \mathrm{Ma})$ tuffs.

\section{Summary and conclusions}

New paleomagnetic results from the hominin-bearing, lake-margin sediments of Area 102, within the northeast Turkana Bain of northern Kenya, provide a reliable magnetostratigraphy for the lower-middle type section of the KBS Member of the Koobi Fora Formation. Early paleomagnetic studies of these sediments typically employed AF blanket treatment in a field of $30 \mathrm{mT}$, which inadequately removed variable remagnetizations, contributing to an unclear stratigraphic position for the top of the Olduvai Subchron-and thus the OlduvaiMatuyama transition-within the KBS Member. As reported here, better results were obtained by progressive thermal demagnetization of 50 independent oriented hand samples. These data are securely placed within the already established stratigraphic framework, which was constructed from lithostratigraphic evidence, the field mapping of marker levels, and tephrostratigraphic correlations. Previously reported radioisotopic dates for the KBS Tuff and the Lower Koobi Fora Tuff allowed for firm correlations between the interpreted polarity intervals and the GPTS. The main conclusions of the study can be summarized as:

- The stratigraphic position of the top of the Olduvai Subchron within the lower-middle type section of the KBS Member was observed at $\sim 48 \mathrm{~m}$ above the base of the KBS Tuff, between ABC marker level C5 ( $\sim 42 \mathrm{~m}$ above the base of the KBS Tuff) and ABC marker level A1 ( $\sim 50 \mathrm{~m}$ above the base of the KBS Tuff). Prior hypotheses that place the top of the Olduvai at either $\sim 25 \mathrm{~m}$ or $\sim 60 \mathrm{~m}$ above the KBS Tuff can therefore be rejected.

- The fine-scale structure for the topmost portion of the Olduvai Subchron in the KBS Member is characterized by alternating reverse-normal polarity changes over $\sim 3 \mathrm{~m}$ stratigraphic interval. Comparable patterns have been identified at other PliocenePleistocene sites, such as from the North Pacific Ocean, North
Atlantic Ocean, loess sequences of China, and Vrica, Italy. Based on these observations, we suggest that the Olduvai Subchron can be subdivided into three polarity subintervals and calibrated using the astronomical dating scheme of the sapropel sequence from the Pliocene-Pleistocene GSSP at Vrica.

- Linear interpolation and extrapolation on the basis of the stratigraphic distribution for the observed polarity intervals, prior thickness measurements of the lower-middle type section of the KBS Member, previously established radioisotopic age control, and the astronomical age of the Olduvai-Matuyama transition suggest that the depositional age of $\mathrm{ABC}$ marker level $\mathrm{A} 2$ is $\sim 1.7 \mathrm{Ma}$. In view of the fact that hominin fossil KNM-ER 3733 was retrieved from about $6 \mathrm{~m}$ above a correlate of the A2 marker level, it is reasonable to infer that this oldest, most complete cranial example of early African $H$. erectus has a depositional age of $\sim 1.7 \mathrm{Ma}$. This age is not greatly different from a prior estimate of $\sim 1.78$. A more accurate age for KNM-ER 3733 will require further geochronological data to be obtained directly at the outcrop from which it was collected.

- A refined stratigraphic position for the top of the Olduvai in the KBS Member may not significantly alter what is already known about the paleogeography or chronology of early Homo dispersals. But together with previously determined radioisotopic dates, paleomagnetic results of this study delimit the age of KNM-ER 3733 to 1.78-1.48 Ma, making it one of the most securely dated fossils of early African $H$. erectus when compared to the oldest Homo fossils from Europe and Asia.

\section{Acknowledgements}

We would like to thank Craig Feibel and the Turkana Basin Institute for providing logistical support. We are especially grateful to Rhonda Quinn, who assisted in measuring sections and collecting a number of the samples used in the study. Our gratitude also extends toward Kenya Wildlife Services and the National Museums of Kenya for facilitating the fieldwork. J. Hillhouse and C. Langereis offered constructive reviews that improved the analytical aspects of the study. The Lamont-Doherty Earth Observatory of Columbia University is acknowledged for the ongoing support of the Paleomagnetics Laboratory. This is Lamont-Doherty Earth Observatory contribution \#7316.

\section{References}

Antón, S.C., Swisher, C.C., 2004. Early dispersals of Homo from Africa. Annual Review of Anthropology 33, 271-296.

Berggren, W.A., Hilgen, F.J., Langereis, C.G., Kent, D.V., Obradovich, J.D., Raffi, I., Raymo, M.E., Shackleton, N.J., 1995. Late Neogene chronology: new perspectives in highresolution stratigraphy. Geological Society of America Bulletin 107, 1272-1287.

Brock, A., Isaac, G.L., 1974. Paleomagnetic stratigraphy and chronology of hominidbearing sediments east of Lake Rudolf, Kenya. Nature 247, 344-348.

Brown, F.H., Feibel, C.S., 1986. Revision of lithostratigraphic nomenclature in the Koobi Fora region, Kenya. Journal of the Geological Society 143, 297-310.

Brown, F.H., Feibel, C.S., 1991. Stratigraphy, depositional environments and palaeogeography of the Koobi Fora Formation. In: Harris, J.M. (Ed.), Koobi Fora Research Project Volume 3: Stratigraphy, Artiodactyls and Palaeoenvironments. Clarendon Press, Oxford, pp. 1-30.

Brown, F.H., Haileab, B., McDougall, I., 2006. Sequence of tuffs between the KBS Tuff and the Chari Tuff in the Turkana Basin, Kenya and Ethiopia. Journal of the Geological Society $163,185-204$

Cande, S.C., Kent, D.V., 1992. A new geomagnetic polarity time scale for the Late Cretaceous and Cenozoic. Journal of Geophysical Research 97, 13917-13951.

Cande, S.C., Kent, D.V., 1995. Revised calibration of the geomagnetic polarity time scale for the Late Cretaceous and Cenozoic. Journal of Geophysical Research 100, 6093-6095.

Cerling, T.E., Brown, F.H., 1982. Tuffaceous marker horizons in the Koobi Fora region and the Lower Omo Valley. Nature 299, 216-221.

Ciochon, R.L., 2009. The mystery ape of Pleistocene Asia. Nature 459, 910-911.

Clement, B.M., Kent, D.V., 1987. Geomagnetic polarity transition records from five hydraulic piston core sites in the North Atlantic. Initial Reports of the Deep Sea Drilling Project 94, 831-852.

Cox, A., Doell, R.R., Dalrymple, G.B., 1964. Reversals of the Earth's magnetic field. Science 144, 1537-1543. 
Dennell, R., 2007. The Colonization of Savannahstan: issues of timing(s) and patterns of hominin dispersals across Asia in the Late Pliocene and Early Pleistocene. American Journal of Physical Anthropology 132 (S44), 98.

Dennell, R., Roebroeks, W., 2005. An Asian perspective on early human dispersal from Africa. Nature 438, 1099-1104.

Feibel, C.S., 1997. A terrestrial auxiliary Stratotype Point and Section for the PlioPleistocene boundary in the Turkana Basin, East Africa. Quaternary International 40, 73-79.

Feibel, C.S., Brown, F.H., McDougall, I., 1989. Stratigraphic context of fossil hominids from the Omo group deposits: Northern Turkana Basin, Kenya and Ethiopia. American Journal of Physical Anthropology 78, 595-622.

Feibel, C.S., Harris, J.M., Brown, F.H., 1991. Neogene palaeoenvironments of the Turkana Basin. In: Harris, J.M. (Ed.), Koobi Fora Research Project Volume 3: Stratigraphy, Artiodactyls and Palaeoenvironments. Claredon, Oxford, pp. 321-370.

Gabunia, L., Vekua, A., Lordkipanidze, D., Swisher, C.C., Ferring, R., Justus, A., Nioradze, M., Tvalchrelidze, M., Antón, S.C., Bosinski, G., Joris, O., de Lumley, M.-A., Majsuradze, G., Mouskhelishvili, A., 2000. Earliest Pleistocene hominid cranial remains from Dmanisi, Republic of Georgia: taxonomy, geological setting, and age. Science 288, 1019-1025.

Gathogo, P.N., Brown, F.H., 2006. Revised stratigraphy of Area 123, Koobi Fora, Kenya, and new age estimates of its fossil mammals, including hominins. Journal of Human Evolution 51, 471-479.

Gibert, L., Scott, G., Ferrandez-Canadell, C., 2007. Evaluation of the Olduvai subchron in the Orce ravine (SE Spain). Quaternary Science Reviews 26, 573-576.

Grommé, C.S., Hay, R.L., 1963. Magnetization of basalt of bed 1, Olduvai Gorge, Tanganyika. Nature 200, 560-561.

Heller, F., Liu, X., Liu, T., Xu, T., 1991. Magnetic susceptibility of loess in China. Earth and Planetary Science Letters 103, 301-310.

Hillhouse, J.W., Ndombi, J.W.M., Cox, A., Brock, A., 1977. Additional results on palaeomagnetic stratigraphy of the Koobi Fora Formation, east of Lake Turkana (Lake Rudolf), Kenya. Nature 265, 411-415.

Hillhouse, J.W., Cerling, T.E., Brown, F.H., 1986. Magnetostratigraphy of the Koobi Fora Formation, Lake Turkana, Kenya. Journal of Geophysical Research 91, 11581-11595.

Horng, C.-S., Lee, M.-Y., Palike, H., Wei, K.-Y., Liang, W.-T., Izuka, Y., Toru, M., 2002. Astronomically calibrated ages for geomagnetic reversals within the Matuyama chron. Earth Planets Space 54, 679-690.

Kirschvink, J.L., 1980. The least-squares line and plane and the analysis of palaeomagnetic data. Geophysical Journal of the Royal Astronomical Society 62, 699-718.

Krijgsman, W., Kent, D.V., 2004. Non-uniform occurrence of short-term polarity fluctuations in the geomagnetic field? New results from Middle to Late Miocene sediments of the North Atlantic (DSDP Site 608). In: Channell, J.E.T., Kent, D.V. Lowrie, W., Meert, J. (Eds.), Timescales of the Paleomagnetic Field. AGU Geophysical Monograph, vol. 145. American Geophysical Union, Washington, D.C, pp. 161-174.

Leakey, M.G., Leakey, R.F., 1978. Koobi Fora Research Project Volume 1: The Fossil Hominids and An Introduction to Their Context, 1968-1974. Clarendon, Oxford.
Lepre, C.J., Quinn, R.L., Joordens, J.C.A., Swisher, C.C., Feibel, C.S., 2007. Plio-Pleistocene facies environments from the KBS Member, Koobi Fora Formation: implications for climate controls on the development of lake-margin hominin habitats in the northeast Turkana Basin (northwest Kenya). Journal of Human Evolution 53, 504-514.

Lourens, L.J., Antonarakou, A., Hilgen, F.J., Van Hoof, A.A.M., Vergnaud-Grazzini, C., Zachariasse, W.J., 1996a. Evaluation of the Plio-Pleistocene astronomical timescale. Paleoceanography 11, 391-413.

Lourens, L.J., Hilgen, F.J., Raffi, I., Vergnaud-Grazzini, C., 1996b. Early Pleistocene chronology of the Vrica section (Calabria, Italy). Paleoceanography 11, 797-812.

Lourens, L.J., Hilgen, F.J., Shackleton, N.J., Laskar, J., Wilson, D., 2004. The Neogene period. In: Gradstein, F.M., Ogg, J.G., Smith, A.G. (Eds.), A Geologic Time Scale 2004 Cambridge University Press, Cambridge, pp. 409-440.

McDougall, I., 1985. K-Ar and ${ }^{40} \mathrm{Ar} /{ }^{39} \mathrm{Ar}$ dating of the hominid-bearing PliocenePleistocene sequence at Koobi Fora, Lake Turkana, northern Kenya. Geological Society of America Bulletin 96, 159-175.

McDougall, I., Brown, F.H., 2006. Precise ${ }^{40} \mathrm{Ar} /{ }^{39} \mathrm{Ar}$ geochronology for the upper Koob Fora Formation, Turkana Basin, northern Kenya. Journal of the Geological Society 163, 205-220.

McDougall, I., Brown, F.H., 2008. Geochronology of the pre-KBS Tuff sequence, Omo Group, Turkana Basin. Journal of the Geological Society 165, 549-562.

McDougall, I., Brown, F.H., Cerling, T.E., Hillhouse, J.W., 1992. A reappraisal of the geomagnetic polarity time scale to $4 \mathrm{Ma}$ using data from the Turkana Basin, East Africa. Geophysical Research Letters 19, 2349-2352.

McFadden, P.L., McElhinny, M.W., 1990. Classification of the reversal test in palaeomagnetism. Geophysical Journal International 103, 725-729.

Ninkovich, D., Opdyke, N.D., Heezen, B.C., Foster, J.H., 1966. Paleomagnetic stratigraphy, rates of deposition and tephrachronology in North Pacific deep-sea sediments. Earth and Planetary Science Letters 1, 476-492.

Spell, T.L., McDougall, I., 2003. Characterization and calibration of ${ }^{40} \mathrm{Ar} /{ }^{39} \mathrm{Ar}$ dating standards. Chemical Geology 198, 189-211.

Swisher, C.C., Curtis, G.H., Jacob, T., Getty, A.G., Suprijo, A., Widiasmoro, 1994. Age of the earliest known hominids in Java, Indonesia. Science 263, 1118-1121.

Tauxe, L., Opdyke, N.D., Pasini, G., Elmi, C., 1983. Age of the Plio-Pleistocene boundary in the Vrica section, southern Italy. Nature 304, 125-129.

Walker, A., 2002. New perspectives on the hominids of the Turkana Basin, Kenya. Evolutionary Anthropology 11, 38-41.

Wood, B.A., 1991. Koobi Fora Research Project Volume 4: Hominid Cranial Remains from Koobi Fora. Clarendon, Oxford.

Zhu, R.X., Potts, R., Pan, Y.X., Yao, H.T., Lu, L.Q., Zhao, X., Gao, X., Chen, L.W., Gao, F., Deng, C.L., 2008. Early evidence of the genus Homo in East Asia. Journal of Human Evolution 55, 1075-1085.

Zijderveld, J.D.A., 1967. A.C. demagnetization of rocks-analysis of results. In: Collinson, D.W., Creer, K.M., Runcorn, S.K. (Eds.), Methods in Paleomagnetism. Elsevier, New York, pp. 254-286.

Zijderveld, J.D.A., Hilgen, F.J., Langereis, C.G., Verhallen, P.J.J.M., Zachariasse, W.J., 1991. Integrated magnetostratigraphy and biostratigraphy of the upper Pliocene-lower Pleistocene from the Monte Singa and Crotone areas in Calabria, Italy. Earth and Planetary Science Letters 107, 697-714. 